\title{
The slotted - displacement ceiling diffuser as an alternative to the organization of down - up air exchange in rooms with computer equipment
}

\author{
Agnieszka Zając ${ }^{1, *}$ \\ ${ }^{1}$ Wroclaw University of Science and Technology, Faculty of Environmental Engineering, \\ Department of Air Conditioning, Heating, Gas Engineering and Air Protection, 4/6 Norwida st. \\ 50-373 Wroclaw, Poland
}

\begin{abstract}
The article analyses heat loads occurring in public utility rooms with computer or multimedia equipment. Attention has been paid to the possibility of using down - up type (displacement ventilation, DV) and up - up type (mixing ventilation, MV) of air exchange. The design of the slotted - displacement ceiling diffuser is presented. The results of measurements in non-isothermal conditions in the form of air flows in the area of its operation are provided. The graphs show the graphical distribution of velocities and air temperatures in the vertical plane passing through the transverse axis of the special diffuser. The study of the behavior of the stream flowing out of the diffuser was only in the scope of work. The velocity and air temperature distribution over the heat sources, which were located away from the diffuser, next to the external walls, was not studied. The focus was on three representative airflows of supply air and the behaviour of the air stream during cooling was presented.
\end{abstract}

\section{Introduction}

Currently, computer or multimedia equipment is widely used, both individually by individuals and in a manner organized by multi-personnel teams. People use electronic equipment for a few or even several hours a day. The presence of a large number of people and computer equipments causes a significant deterioration of air quality, and in the absence of efficient air-conditioning contributes to the reduction of user concentration and reduced performance. Favourable microclimate conditions negatively affect the well-being, improve the reception of information and, as a result, the desired increase in work efficiency. One of the important factors of the room's microclimate are the thermodynamic air parameters and velocity in people's occupancy area [1].

Such rooms are located in buildings:

- for educational purpose (computer rooms in schools, at universities, in educational centres),

- offices (training rooms in banks, telecommunications),

- entertainment (gaming rooms, internet cafes),

* Corresponding author: agnieszka.zajac@pwr.edu.pl 
- production (monitoring and supervision rooms, rooms for regulation and control of technological processes).

In such rooms the microclimate can be shaped by different ventilation or air conditioning systems or devices [2]. Both individual devices or central systems with energy recover in heat exchangers or recirculation may be used. Systems with a constants air volume CAV and variable air volume VAV are known. More and more often devices with two-stage air treatment using fan-coils, air conditioners, chilled beams or split indoor units are found.

The main sources of heat gains in the rooms are [3-5]:

- used electronic equipment,

- computer support personnel,

- solar radiation through transparent partitions, if any,

- electric lighting.

The analysis of heat gains has shown that the heat balance of rooms is dominated by heat gains from electronic equipment and occupants [4]. These profits amount to $80-85 \%$ and they are practically fixed (they change to a small extent during the year). From other sources (solar radiation, lighting), profits are much smaller and do not exceed $20 \%$. However, they are variable and depend on the time of use, outdoor conditions and sun exposure.

The unit thermal loads of the analysed rooms often exceed $100 \mathrm{~W} / \mathrm{m}^{2}$ [4].

The high saturation of rooms with electrical and electronic equipment means that the thermal energy that is emitted should be assimilated throughout the year. Penetration losses are largely limited. After all, the standard has become the use of energy-saving technologies for erecting buildings, good insulation of external partitions, triple glazing, solar protection and thoughtful orientation of the building according to the sides of the world.

In winter, heat balance values are reduced, but negative (minus) values are achieved only in rooms where internal heat sources (electronic equipment, electric lighting) are turned off and there is a lack of people. Solar radiation on external barriers (transparent) can only decide on temporary fluctuations in thermal balance values. The heat balance comes to $50-70 \%$ of the value from the summer period in the laboratories used from the winter period [4].

\subsection{Organization of air exchange}

One of the basic tasks of a ventilation / air conditioning system designer is to achieve proper and effective air distribution in a room [5]. There are known guidelines for designing a properly operating ventilation or air conditioning system [1-3]. First of all, the entire occupancy area must be constantly cleansed by the supply air, and its velocity and air temperature should be chosen so as not to cause a feeling of drafts. Secondly, the air can only be removed if its assimilation capacity is fully utilized. It results from this that the air flow cannot be accidental, but must be appropriately organized.

Organizing air exchange comes down primarily to $[1-3,5]$ :

- proper location of supply and exhaust diffusers, depending on the shape of the room, its dimensions, purpose, architectural finish or interior design,

- proper placement of supply and exhaust diffusers in relation to sources of heat, steam and pollution,

- provide supply air streams the right direction and speed in order to wash the entire occupancy area at the appropriate velocity and air temperature. 
There are four basic systems of air circulation in ventilation and air condition systems in a room defined by flow directions $[7,8]$. The most commonly used ones are two of them: down - up type (displacement system DV) and up - up type (mixing system MV).

Exemplary air flow patterns for the organization of a given type are shown in the Figs. 1 and 2 .

a)

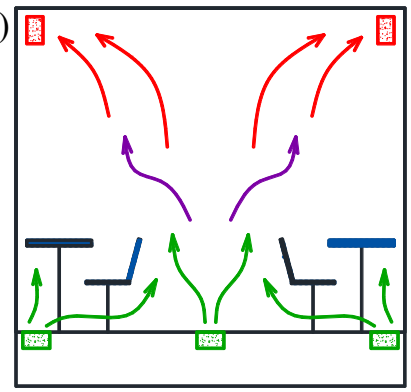

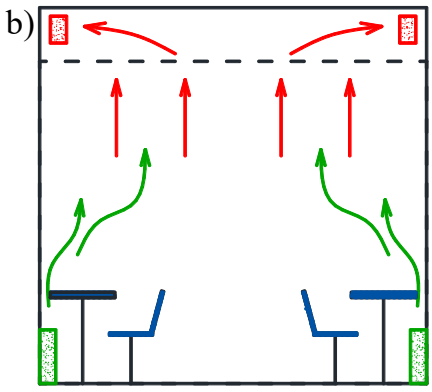

Fig. 1. Diagrams of air flow in a computer lab of a down-up type.

In the displacement system (down-up type), the air is supplied at the floor level at the velocity closest to the recommended one for comfort conditions in the occupancy zone $(<0.5 \mathrm{~m} / \mathrm{s})$ and the air temperature close to the room (difference not more than $2-3 \mathrm{~K}$ ) [7-11]. This airflow is carried out by displacement diffusers placed in the floor or along the walls (Figs. 1a, 1b i 1c). The air moving in the floor zone heats and rises, assimilating unnecessary heat gains after encountering the heat sources. The air movement is supported here by the natural phenomenon of free convection. The air is exhausted from the upper zone. However, in order to remove heat gains, it is necessary to increase the airflows or reduce the supply air temperature. Too low temperature and too high velocity may cause an unpleasant feeling of drafts. Temperature of supplied air should be $19^{\circ} \mathrm{C}$ or higher [15]. In addition, when using floor diffusers, the accumulation of dust and particulate matter in them and their circulation around the room together with the air flow becomes a problem $[13,14]$. Maximum unit heat loads, assimilated by a positive displacement ventilation system amount to $40-50 \mathrm{~W} / \mathrm{m}^{2}[12]$.

In the up-up organization (mixing system), the air is supplied from the ceiling area with a high initial velocity $(2-6 \mathrm{~m} / \mathrm{s})$ of the supply elements characterized by high inductance and turbulence [7,8]. Supply air streams must have the necessary energy to counteract the convection currents generated in the room. The air flows through the entire height of the room along the way, absorbing the impurities, flows into the people's occupancy area at the velocity of $0.25-0.4 \mathrm{~m} / \mathrm{s}$, and then as already heated it floats to the upper zone into the exhaust area [16-19]. Placement of exhaust diffusers above the occupancy area allows for taking higher values of air temperature rise in room, and thus, ventilating the room with a smaller airflow. Fresh air is supplied through the upper part of the room at a temperature of $16^{\circ} \mathrm{C}$ or less [15]. The arrangement of air supply elements in the upper part does not limit changes in the decor and the function of the room, and the supply elements will not be covered with equipment elements. However, one should pay a lot of attention to the type of ceiling finishing: joists, beams, lighting lamps, panels etc., which may interfere with the proper placement of diffusers and air exhausters. 
a)

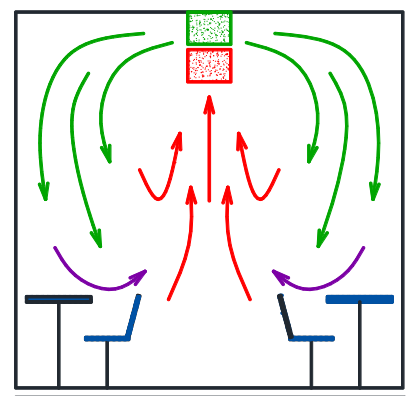

d)

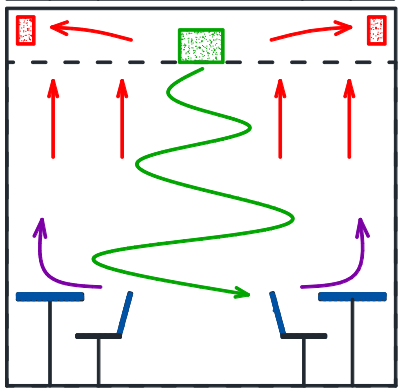

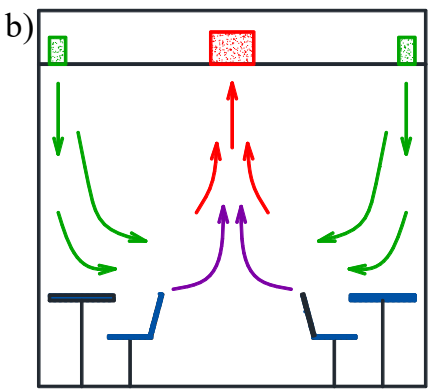

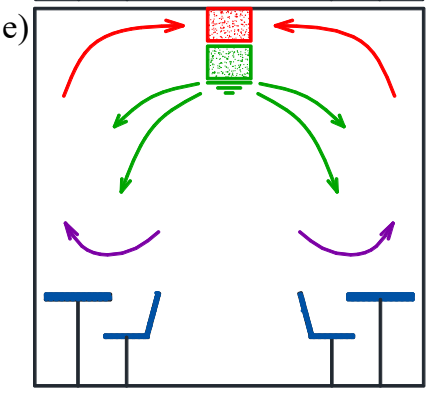

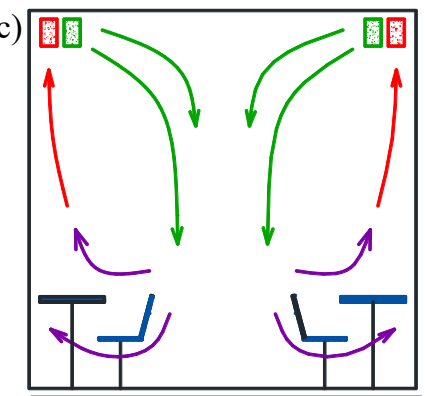

f)

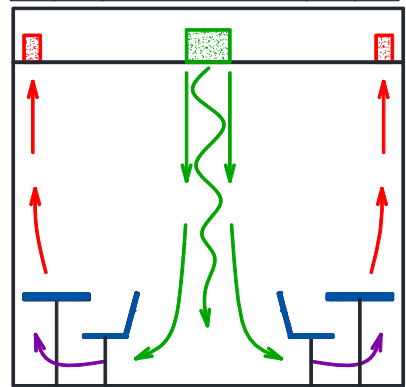

Fig. 2. Diagrams of air flow in a computer lab of a up-up type.

\section{The slotted - displacement ceiling diffuser}

The main task of ceiling diffusers is to provide air in a way that does not discomfort users, and even allows for correct air exchange in terms of thermal sensation, despite the disadvantageous system of an up-up air exchange organization. It is an activity against the principles of physics, because warm air has a natural tendency to rise upwards. In addition, if the diffusers and exhausters are incorrectly placed in room, the air will mix with the convection-drifted streams of used air (which assimilated heat and moisture from people and other sources) [20], as in Figs. 2a and 2b.

However, it is possible to resolve the supply elements and such arrangement of diffusers and exhausters in the room so that convection currents from occupants and electronic equipment are used and the thermal sensations of the users are correct. This possibility is provided by the slotted - displacement ceiling diffuser of its own construction design.

\subsection{The construction of the diffuser}

The airflow flowing out from the central part of the diffuser is characterized by high inductance and marked turbulence. On the outside, it is limited by air intakes that prevent from spreading to the users' heads. By reducing the intense mixing, the air stream is brought above the floor in an unchanged geometric form, without spreading from side to side, and thus only a small air suction takes place. It begins to grind on the floor, and when encountering heat sources assimilates their excess and supported by convective streams, floats up, straight to the exhaust installation (Fig. 2f). This operation of this diffuser has been confirmed by research in real conditions on a test bench simulating the actual processes $[4,6]$. The advantages of displacement ventilation and down - up air exchange by supplying air to the room zone with the smallest unit heat gains and its exhaust from heat sources are used. 
A picture of the diffuser is shown below, in Fig. 3, from which the air flows out through the centre perforated surface and two gaps, pre-limiting and directional supply air. The dimensions of the front panel of the diffuser are as follows $0.6 \times 0.4 \mathrm{~m}$.

a)

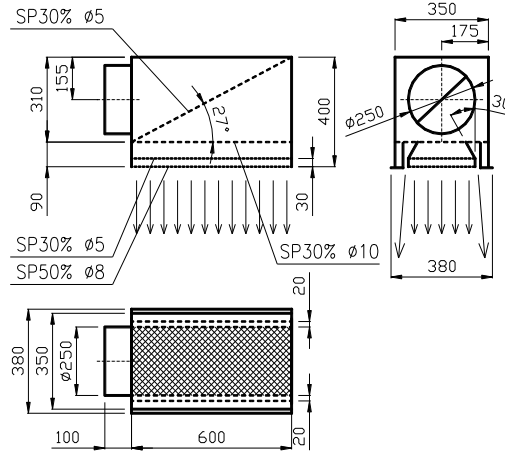

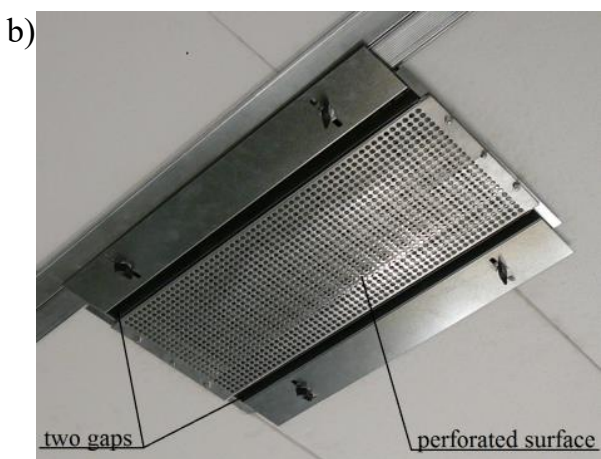

Fig. 3. a) Construction diagram of the slotted-displacement ceiling diffuser of its own design, b) ceiling diffuser prototype with limiting air jet $[4,6]$.

\subsection{Measurement results}

The study used experimental measurements in a full-scale test room with dimensions of $4 \mathrm{~m}$ width $\times 3 \mathrm{~m}$ length $\times 2.85 \mathrm{~m}$ height and a sophisticated HVAC control system. Air temperature and velocity measurements were carried out at different distances from the supply air diffuser. Tests were conducted on sixteen measurement levels, at a distance of $0.3 \mathrm{~m}, 0.45 \mathrm{~m}, 0.6 \mathrm{~m}, 0.75 \mathrm{~m}, 0.9 \mathrm{~m}, 1.05 \mathrm{~m}, 1.2 \mathrm{~m}, 1.35 \mathrm{~m}, 1.6 \mathrm{~m}, 1.75 \mathrm{~m}, 2.05 \mathrm{~m}$, $2.2 \mathrm{~m}, 2.35 \mathrm{~m}, 2.5 \mathrm{~m}, 2.65 \mathrm{~m}, 2.8 \mathrm{~m}$ from the floor. The measurements were carried out mainly in the longitudinal and transversal axes of the diffuser containing 29 vertical measuring lines. Measuring grid points have been spaced at intervals of 0.05 or $0.1 \mathrm{~m}$. During the tests, the volume of airflows (from 325 to $625 \mathrm{~m}^{3} / \mathrm{h}$ every $75 \mathrm{~m}^{3} / \mathrm{h}$ ), the width of the gaps limiting the stream (from 0 to $45 \mathrm{~mm}$ every $5 \mathrm{~mm}$ ), and the degrees of perforation of the outer plate and the internal plates levelling the flow (from 20 to 50\% every $10 \%$ ) were changed. With larger airflow than $625 \mathrm{~m}^{3} / \mathrm{h}$ in the area around the occupant zone, the velocity exceeded the value of $0.5 \mathrm{~m} / \mathrm{s}$. The share of air flowing through the gaps in relation to the total supply air fluctuated from 30 to $60 \%$.

Initially, the tests were carried out in quasi-isothermal conditions when the difference between the temperature of the supply air and the laboratory tested did not exceed $1 \mathrm{~K}$. Such conditions are in fact rare but it is possible to see the real cross section through the supply jet. At very low outside air temperatures, the ventilation / air conditioning unit also fully or partially fulfils the role of heating. Then the supply air must have a higher temperature. However, for a significant part of the year, it is necessary to assimilate the heat generated by the devices and people. The supply air temperature must therefore be lower than in the room. The next step, therefore, was to test the behaviour of the supply air stream when heating and cooling the air in the room (non-isothermal conditions). The temperature difference between supplied and ambient air in both cases was $5 \mathrm{~K}$.

This publication presents the test results only of the diffuser with $20 \mathrm{~mm}$ wide gaps, perforation internal plates of $30 \%$ and outer plate of $50 \%$. The velocity distribution for the transverse axis was chosen as the most interesting, because it represents the flow of the stream towards the heads, neck and back of users. Only the work of the cooling function is presented because the need to heat such rooms occurs sporadically. 
The obtained measurement results in the form of a graphic velocity and temperature distribution (in vertical planes passing through the transverse axis of the diffuser) for three different airflows are depicted on the diagrams (Figs. 4, 5 and 6). The diagrams show only a part of the room width, under the diffuser. The measurements were conducted with attached simulation systems for heat gains from people and computers. Heat sources were placed near the outer walls, away from the diffuser. The diagrams do not show a crosssection through the entire room. The focus was only on the stream of air blowing from the diffuser. The air temperature and velocity distribution over the heat sources and local convective flows arising there are not shown because it did not come within the scope of research. No vertical air temperature gradient above the heat sources has been studied.

a)
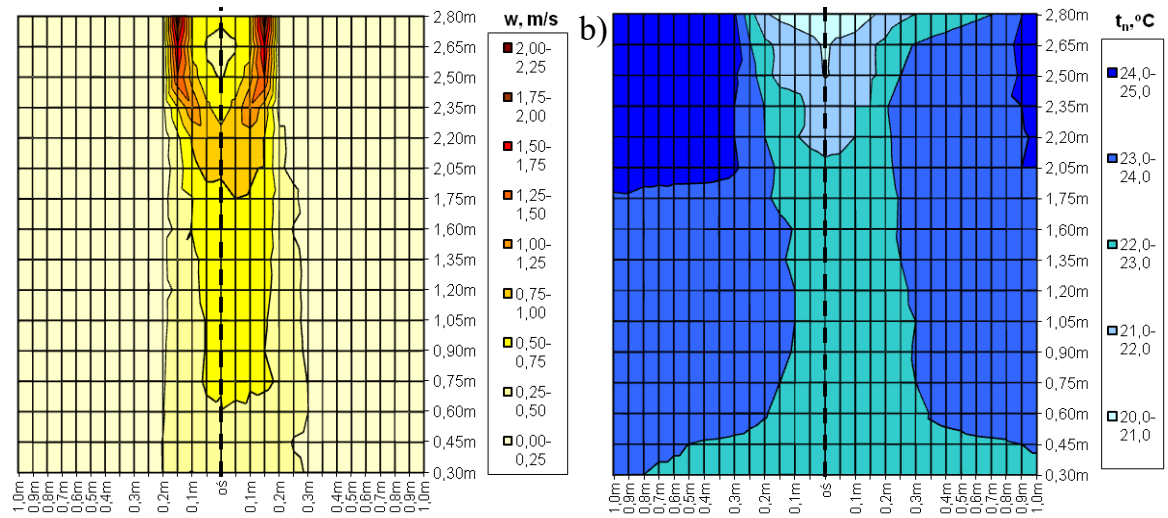

Fig. 4. Distribution of air a) velocity b) temperature in the area of operation of the diffuser during cooling of the room (supply airflow $400 \mathrm{~m}^{3} / \mathrm{h}$, supply air temperature $20^{\circ} \mathrm{C}$ ).

a)

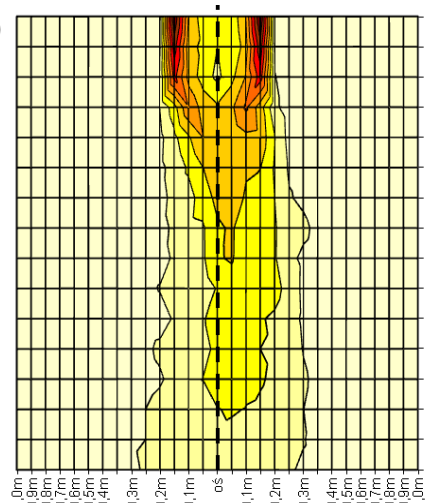

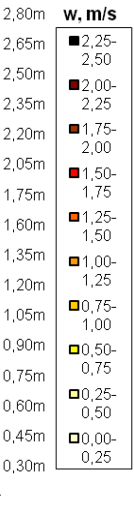

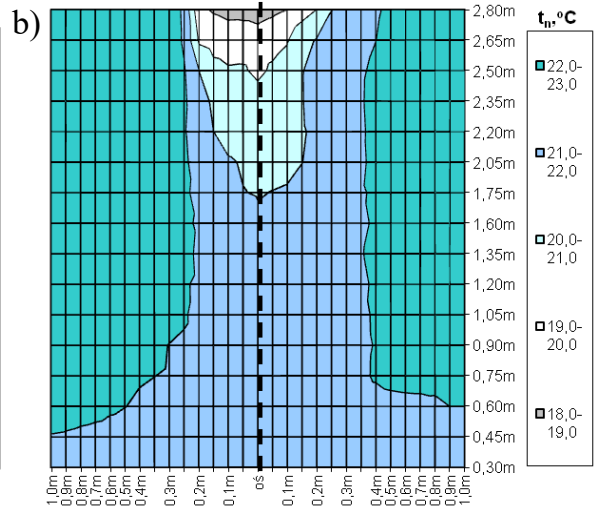

Fig. 5. Distribution of air a) velocity b) temperature in the area of operation of the diffuser during cooling of the room (supply airflow $475 \mathrm{~m}^{3} / \mathrm{h}$, supply air temperature $18.5^{\circ} \mathrm{C}$ ).

With a constant gap width of $20 \mathrm{~mm}$, the average velocity of air outflow from the centre perforated part was in the range of $0.45-0.85 \mathrm{~m} / \mathrm{s}$, while it was $1.65-3.25 \mathrm{~m} / \mathrm{s}$ from the limiting gaps. A velocity of $0.4-0.8 \mathrm{~m} / \mathrm{s}$ was found under the diffuser in the occupancy area. In addition to the area of operation of the diffuser, i.e. where people are continuously present, the velocity was about $0.2 \mathrm{~m} / \mathrm{s}$. The range of increased velocities can be observed in the transition between computer stations, where a person is temporarily staying and moving. A shorter, higher airflow should be perceived by users as refreshing $[21,22]$. The zone of elevated velocities, the so-called impact zone of the diffuser, was from 0.3 to $0.6 \mathrm{~m}$. 
These considerations were validated by experimental visualization. Fig. 7 shows the photo of jet spreading by smoke test. As shown in Fig. 7a in case of $0 \mathrm{~mm}$ air-restricting gaps the air has a tendency to scatter in the room and larger turbulence. The use of $20 \mathrm{~mm}$ wide gaps strongly limits the supply air that reaches the floor area as a compact stream. It leads to a lower degree of mixing with the ambient air as shown in Fig. 7b.

a)

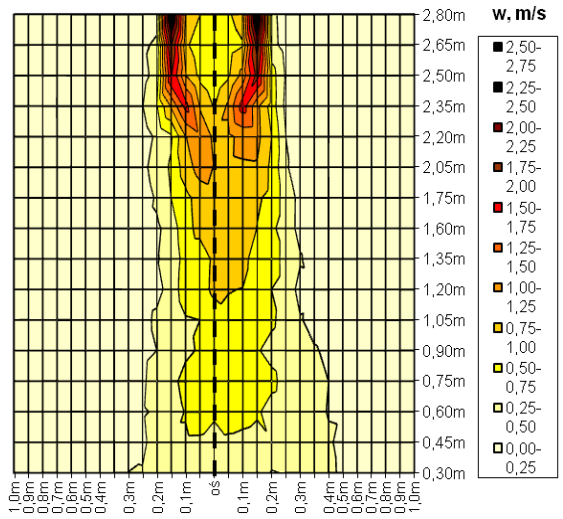

b)

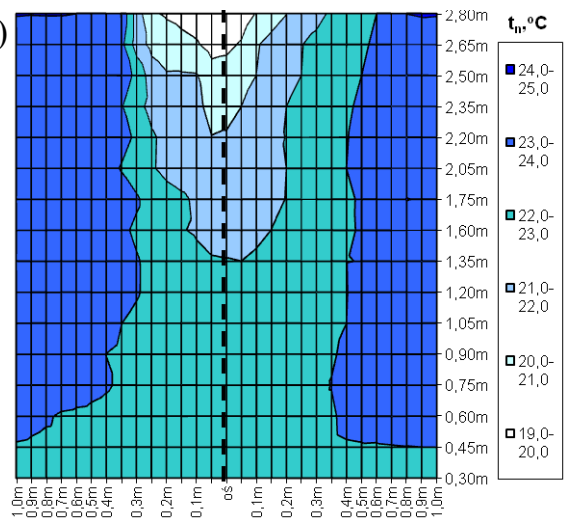

Fig. 6. Distribution of air a) velocity b) temperature in the area of operation of the diffuser during cooling of the room (supply airflow $550 \mathrm{~m}^{3} / \mathrm{h}$, supply air temperature $19^{\circ} \mathrm{C}$ ).

a)

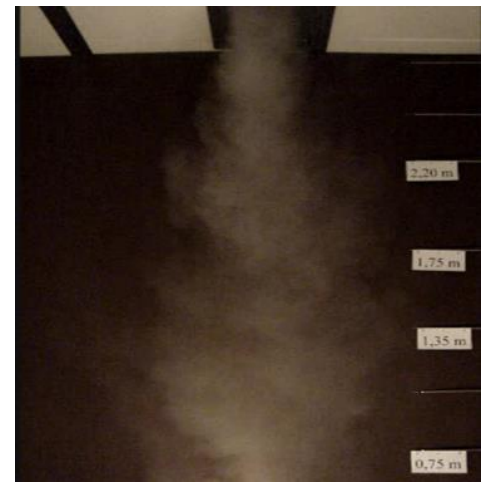

b)

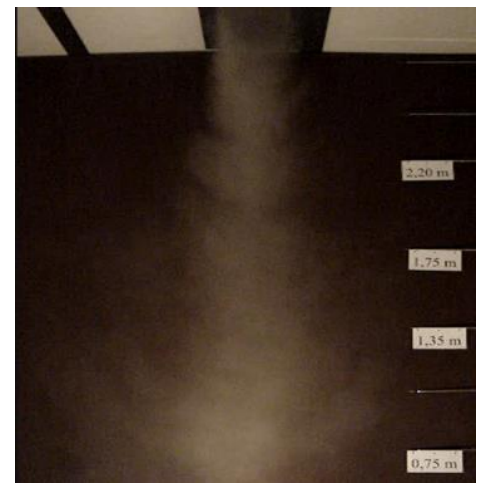

Fig. 7. Visualization of the airflow from the diffuser by smoke (supply airflow $400 \mathrm{~m}^{3} / \mathrm{h}$, different gap width a) $0 \mathrm{~mm}$, b) $20 \mathrm{~mm}$ ).

\section{Conclusion}

In currently emerged buildings, rooms saturated with electronic, computer and multimedia equipment are commonly found. The density of electronic equipment and people on a small area means that individual heat gains often exceed significantly $100 \mathrm{~W} / \mathrm{m}^{2}$ [4]. Such high thermal loads usually require an additional cooling system. Assimilation of higher loads by positive displacement ventilation is possible in the case of high rooms with low requirements for external air flow. Then it is possible to use additional devices in the form of fan-coils, chilled beams, VRF or split indoor units and air conditioners in order to receive unnecessary heat gains from the room [2]. Another way is to use very large diffusers, unless there are any architectural and construction restrictions [3]. This applies specially to existing rooms, modernized and adapted to new functions. It is proposed to organize the air exchange system with the slotted - displacement ceiling diffusers of the original construction as an alternative solution to the most recommended systems with floor 
diffusers. The article presents selected results of measurements of the diffuser in nonisothermal conditions. Both graphical distribution of velocities and air temperatures (Figs. 4-6) and visualization with smoky air (Fig. 7) show obtained regular and limited air flow. Analysis of the test results shows that the use of limiting gaps cause a more even distribution of the stream in the occupancy area, which reaches the lower layers of air as in Fig. 7. This air flow organization allows for the assimilation of heat similar to that for overhead mixing ventilation MV while simultaneously meeting, in the area of workplaces and continuous residence of people, all the advantages of a positive displacement system DV.

The work was realized within the allocation No. 0401/0007/17 awarded for Faculty of Environmental Engineering Wroclaw University of Science and Technology by Ministry of Science and Higher Education in years 2017-2018.

\section{References}

1. ASHRAE Handbook, HVAC Application (2011)

2. E. Przydróżny, Wysokosprawne systemy wentylacji i klimatyzacji - technologia i projektowanie 50, 214 (2007)

3. A. Pełech, S. Szczęśniak, Wentylacja i klimatyzacja: zadania z rozwiązaniami i komentarzem, 285 (2012)

4. A. Zając, Shaping air parameters in rooms with significant, concentrated heat gains, $\mathrm{PhD}$ thesis, 145 (2008)

5. W.P. Jones, Air conditioning engineering, 513 (2001)

6. G.J. Besler, A. Zając, International Conference Air \& Heat 12, 6 (2008)

7. H.B. Awbi, Front. Mech. Eng. 1, 4 (2015)

8. G. Cao, H. Awbi, R. Yao, Y. Fan, K. Siren, R. Kosonen, J.J. Zhang, Biuld. Environ. 73, 16 (2014)

9. X. Shan, J. Zhou, W.C. Chang, E.H. Yang, Build. Environ. 102, 10 (2016)

10. K.S. Lee, T. Zhang, Z. Jiang, Q. Chen, ASHRAE Trans. 115, (2009)

11. H. Yin, A. Li, Z. Liu, Y. Sun, T. Chen, Biuld. Environ. 109, 9 (2016)

12. S.D. Hamilton, K.W. Roth, J. Brodrick, ASHRAE J. 9, 3 (2004)

13. F. Causone, F. Baldin, B.W. Olesen, S.P. Corgnati, Energy Build 42, (2010)

14. A. Lipczynska, J. Kaczmarczyk, A.K. Melikov, Build. Environ. 92, 12 (2015)

15. N.M. Mateus, G. Carrilho da Graca, Build. Environ. 114, 13 (2017)

16. D. Müller, C. Kandzia, R. Kosonen, A.K. Melikov, P.V. Nielsen, REHVA guidebook, 19 (2013)

17. T. Arghand, T. Karimipanah, H.B. Awbi, M. Cehlin, U. Larsson, E. Linden, Build. Environ. 92, 13 (2015)

18. A. Makhoul, K. Ghali, N. Ghaddar, Build. Environ. 60, 11 (2013)

19. B.W. Olesen, A. Simone, M. Krajcík, F. Causone, M. DeCarli, Int. J. Vent. 9, 13 (2011)

20. M. Karpuk, A. Pełech, E. Przydróżny, J.J. Walaszczyk, S. Szczęśniak, International Conference ASEE17 22, 9 (2017)

21. R. Tomasi, M. Krajcik, A. Simone, B.W. Olesen, Energ. Buildings 60, 10 (2013)

22. W. Wu, Z. Lin, Biuld. Environ. 85, 9 (2015) 